2009

\title{
The Transformation of Work, the Disappearance of 'Workers', and the Future of Workplace Regulation
}

Harry W. Arthurs

Osgoode Hall Law School of York University, harthurs@osgoode.yorku.ca

Follow this and additional works at: http://digitalcommons.osgoode.yorku.ca/all_papers

\section{Repository Citation}

Arthurs, Harry W., "The Transformation of Work, the Disappearance of 'Workers', and the Future of Workplace Regulation" (2009). All Papers. Paper 4.

http://digitalcommons.osgoode.yorku.ca/all_papers/4 
Transform work oxford09

THE TRANSFORMATION OF WORK, THE DISAPPEARANCE OF "WORKERS", AND THE FUTURE OF WORKPLACE REGULATION

\section{St. John's College, University of Oxford 26 November 2009}

\section{Introduction}

If you have read my curriculum vitae you will not have seen the publication that inspires my remarks this evening. As I was waiting to go off to Harvard to do my master's degree, I was offered work revising a publication known as the Canadian Encyclopaedic Digest. In particular I was asked to update the chapter on "street railways" - what you would likely call "trams". Sections of the chapter covered such illuminating topics as "sounding the gong" and "using the cowcatcher". It was boring, stupid work, but I had to do It for money. What added injury to insult, however, was the fact that no one had travelled on or spoken of, much less sued, a "street railway" since the original chapter was written in the 1920s.

In preparing my remarks for this evening, the thought occured to me that fifty years hence, someone may give a lecture at St. John's reminiscing about a youthful assignment to update a chapter on "workers" or "labour law" or "industrial relations", terms that in the interval had ceased to refer to any extant subject of academic interest or human endeavour.

A little excursion into history will set the stage for this glimpse into a possible future without labour market regulation. From 1945 or 1950 to, say 1970 or 1975, workers in most advanced economies enjoyed rising wages; more secure job tenure within the internal labour market of the enterprise; greater protection of their health, safety and dignity; and improved access to social benefits, such as pensions and health insurance, whether provided by the state 
or by their employers. These improvements didn't just fall from the sky. They were secured through the efforts of unions and of social democratic and social market parties, in the context of favourable labour market conditions associated with an expanding economy and productivity gains and against the backdrop of a general desire to avoid the social conflict of the interwar and wartime years.

In the 1970s, however, labour markets conditions began to change in response to larger developments in the global political economy. These changes, in turn, came to be reflected in the nature of work and character of workplaces and in the social, cultural and political significance of "work" and "workers". The result, I will argue, is that the forms of workplace regulation that seemed to serve us well during the earlier period no longer do.

\section{The transformation of work}

The transformation of work in advanced western economies over the past thirty or forty years has been well-documented and widely discussed. Consequently, I will simply tick off a few items on a long list of relevant historical developments. Of course, these developments have occurred in different ways and to different degrees in different states and sectors of the economy.

Technology, first. As we all know, technology has been changing work. While no doubt it has reduced human drudgery, enhanced productivity and triggered some positive changes in society as a whole, it has also had a number of consequences prejudicial to the interests of some workers and to worker solidarity and power in general.

- It has intensified the functional division of labour and its geographical dispersal, thus attenuating social relations and psychological ties amongst workers. 
- It has polarized the workforce, creating a relatively privileged cadre of highly educated and skilled workers (what Galbraith called the "technostructure") but consigning many unskilled and semi-skilled workers to the margins of the labour market.

- It has transformed the strategies used by management to control the work process and the workforce, with highly skilled workers in effect moving towards a degree of self-management, and unskilled workers increasingly disciplined by their job routines and monitored by their computers.

- It has set in motion continuous and accelerating change in the content of virtually all work, thus assuring the rapid obsolescence of workers' jobspecific knowledge and the devaluation of their human capital.

A closely related development is the dramatic shift in employment from manufacturing to the service sector. During the postwar period, the manufacturing sector in many countries had come to be characterized by strong internal labour markets, tenured employment, widespread trade union membership, decent wages and generous job-related benefits, such as pensions. Consequently, as large numbers of manufacturing jobs were lost, especially from the 1970s onwards, many of these characteristic features of workplace life went into decline as well. Certainly, they were not generally replicated in the service sector, which has been characterized by relatively low wages and modest benefits, insecure employment and low levels of union membership.

Flexibilization of the workforce is often seen by employers as an essential strategy for responding to rapid changes in markets or machines. Workers they contend - must not regard any job as permanent; they must be willing and able to take on new work assignments within the enterprise as required; they must be easy to replace if they cannot do so; and, if there is no work for them, they must accept redundancy without undue cost or delay. Furthermore, 
employers have developed various arrangements that enable them to rapidly mobilize and demobilize a reserve army of labour. These arrangements include the creation of part-time, seasonal and short-term jobs, and the use of temporary agency workers. And finally, employers have gained additional flexibility by outsourcing work altogether rather assigning it to members of their core work force. This strategy enables them not only to offload labour costs but to shift other business risks from themselves to subcontractors and suppliers. Needless to say, flexibilization has undermined the operation of internal labour markets and helped to ratchet downward wages, benefits, the incidence of tenured employment and levels of unionization. It has also intensified competition for available work amongst workers employed by any given employer and between them and other workers who benefit from outsourcing practices.

Demography comes next on my list of transformative changes in the world of work. The gender and race composition of the workplace has changed. White males no longer predominate. Despite persistent and subtle forms of discrimination, and despite the existence of job ghettoes, most jobs are now accessible to women, to people of various provenances, hues and faiths, and to disabled people. The age composition of the workforce has also changed: young people are likely to be older than they used to be when they start work, if they are lucky enough to get it at all; and aging workers are more likely to be healthy towards the end of their careers, and in some countries, are protected against mandatory retirement, if not against the perils of a failing pension system. Diversity, in other words, has become a dominant feature of contemporary workplaces. This is as close to an "unqualified human good" as we are likely to get. However, the result is that members of different demographic groups compete for work and wages, seek to define job content and prerogatives in ways that suit their particular needs, and are quick to blame "the other" if things go wrong. Solidarity is difficult to maintain in these circumstances. conditions. 
And how could I fail to mention globalization? Globalization is, of course, made possible by technology. Thanks to developments in communications and transportation, most work can be done anywhere in the world. This has, in effect, created a new and vastly enlarged global labour market. At one point, it appeared that this might in turn lead to a new international division of labour in which the workers in the global North would retain "good jobs" - those requiring education, training, skills and sophistication — while "bad jobs" would be sent offshore to workers in the global South. However, things didn't quite turn out that way at all. As we now know, it turns out that given a bit of time and training, workers in the global South are capable of performing very sophisticated work indeed and at much lower rates of pay than their comrades in the global North.

Thus globalization has had profound consequences. Employers in the advanced economies now have an exit option: they can move both manufacturing and service work away from their formerly well-paid, unionized workers to workers in countries where much lower pay prevails and unions are blessedly absent. Not that employers necessarily need to move abroad or even threaten to move: the mere knowledge of the possibility makes workers in the global North more willing to work for less and to stay out of unions.

To sum up, over the past thirty or forty years, developments in the nature, organization and location of work have increased the precarity of employment, created conflicts or magnified differences amongst workers in individual workplaces, across economies and around the world, undercut labour solidarity and union strength, and shifted the balance of power in favour of employers both in individual enterprises and in labour markets more generally. 


\section{The disappearance of "workers"}

As a labour lawyer, I'm well aware of proposals to reverse these developments which have been so negative for workers. Some involve tweaking existing legislation to improve its administration, extend its reach or reinforce its substantive requirements. Some involve the aggressive use of new contract- or tort-based legal strategies to deter employers from the abuse of their workers. And some involve the formal constitutionalization of labour rights, embedding them in international legal regimes such as the WTO or using government contracts or largesse as an inducement to persuade employers to commit to observing higher labour standards at home and abroad.

Many of these proposals are laudable on their merits, but none of them is likely to reverse the structural changes I have described in the nature and organization of work, in the bargaining power of individual workers, and in the strength of unions. Still less are they likely to prevent the disappearance of "workers" as a political and industrial force, as a social and cultural category and as the concept that organizes our thinking about labour law and policy.

Obviously, I cannot document the extent to which people once defined themselves as "workers" or as members of the "working class", but these terms certainly sound anachronistic these days. People are much more likely to define themselves as consumers rather than producers: as wearers of Nikes or drivers of Smart Cars, as vegans or evangelicals, as Arsenal supporters or Oxford graduates. If they experience unfairness, whether in the workplace or elsewhere, they tend to experience it not as "workers" but as members of a disenfranchised group - understandably as Asians or gays or sightless people do or perversely, as do BNP members who imagine themselves to be victimized because of their "indigenous British ethnicity". The common experience, the solidarity-building experience, of workers - in mines and sweatshops and dark satanic mills - is gone. Gone too is the culture that reinforced that solidarity: the 
Durham Miner's Gala survives but its power is more Proustian than Fabian or Marxian; Coronation Street has become a parody of itself; and the cloth cap and council flat, the scruffy pub and chip shop are no longer reliable predictors of shopfloor militancy and Labour politics.

I pause here to acknowledge that like all ideal-types or stereotypes, the picture I have drawn of workers past and workers present is too simple by far. And I acknowledge as well that in an absolute sense, most working people are better off than they used to be, say, sixty years ago. The point I do press on you, however, is that to whatever extent a robust working class culture, identity and solidarity once existed, these are now greatly diminished if not gone altogether. In that qualitative sense, "workers" have disappeared as a sociological category.

In a quantitative sense, however, they are still very much a presence in British society, and in North American society too. If income is any indication of class status, and if one's job is a determinant of income, workers ought to be a larger, more united and more aggressive presence than they were thirty or forty years ago. Income inequality during that time has grown markedly; and with it inequality in the lives people lead: in their morbidity and mortality rates; in their educational and occupational opportunities; in their participation in civic affairs and politics; in their receipt of social entitlements and enjoyment of legal rights. Many villains have been held responsible for the failure of workers and other subaltern groups to unite in reaction to this growing inequality. They range from America's neo-conservatives to Britain's New Labour, from fatty foods to false consciousness. But whoever the villains may be, it seems clear that they have largely succeeded: workers are no longer a force to be reckoned with. Their industrial movement is in disarray and their political movement verges on disaster.

Nor do labour issues often play a central role in political debates as they once did, for example, in the UK elections of 1964, 1974 and 1979 and still do 
occasionally and in distant places, such as Australia in its 2007 federal election. Nor are they likely to any time soon, given the declining ability of trade unions in most countries to "deliver the vote", their diminishing influence within Labour and Social Democratic parties, and the dwindling public interest in and media coverage of labour issues (public service strikes always excepted).

Nor has the virtual disappearance of workers and the working class escaped the attention of governments. To cite but one example, the governments of many countries, including yours and mine, have "disappeared" their labour ministries, in the Latin American sense of the term. In Canada our Department of Human Resources and Skills Development has taken over the functions of the old Labour Department. In the UK, functions once assigned to the Ministry of Labour have migrated to the Ministries of Work and Pensions, Education and Employment and Business, Innovation and Skills. Workers, then, are no longer a constituency with moral claims, voice and agency, not even a sinister force to be either placated or suppressed. Rather they have become a mere "resource" to be "developed" through "education" and "skills" training in order to facilitate "innovation" and improve the performance of "business". Labour market and industrial relations policies have accordingly become mere by-products of fiscal, monetary, trade, human rights and social welfare policies.

\section{The future of workplace regulation}

This is a far cry from what we used to think of as the underlying mission of labour policy and labour law - to make life better for workers. That mission took different forms. Sometimes the state intervened to extend protection to women, children and other workers deemed most at risk; sometimes it sought to restructure labour markets to achieve full employment and to buffer workers against the worst consequences of unemployment; and sometimes it passively allowed or actively assisted workers to aggregate and exercise collective or 
countervailing power. But under the new dispensation, none of those approaches seems to hold much attraction or promise much success.

Not protecting the most vulnerable workers: A couple of years ago, I chaired a commission on labour standards legislation for our federal government. My report was the product of two years of hard work, extensive consultation, sophisticated research, and the expenditure of $\$ 5$ mil. It sank like a stone, ignored by the government and unnoticed by the media. Almost unnoticed, that is. It did attract one editorial. I quote it pretty much verbatim: "Prof. Arthurs has recommended the establishment of a national minimum wage. This is the same sort of fuzzy thinking that leads people to oppose child labour." This position was a little extreme: many governments have outlawed child labour, established minimum wages and taken steps to introduce a floor of labour standards below which no worker is to be allowed to fall. But still, labour standards in many countries remain quite low, are seldom updated to take account of changes in the economy, and are seldom enforced with regularity or vigour.

Not restructuring the labour market to ensure full employment: globalization has forced states to foreswear many of the strategies they once used to control labour markets; monetarist policies have put employment policy in the hands of finance ministers and central bankers; and neo-liberalism has so captured the imagination of most governments that the very idea of "regulating" a market is anathema.

And certainly not collective bargaining: The failure so far by the the U.S. Congress to pass the so-called Employee Freedom of Choice Act illustrates my point. It represents a very modest effort to resuscitate collective bargaining in America, and if enacted, it would be the first such statute to do so since the original National Labour Relations Act of 1935. Nonetheless, in the current economic crisis, its proponents seem resigned to see it scaled down, delayed or defeated, despite the fact that their party is in nominal control of Congress. 
The fact is that especially in the current economic crisis even presumptively labour-friendly governments are nervous about adopting labour legislation for fear of provoking business opposition, capital flight and the loss of tax revenues and jobs. A graffito I once saw in Swiss Cottage says it all: "The economy is the secret policy of our desires." And like the East German Stasi, the economy is everywhere, not just spying on us, not just threatening us, but invading our thoughts, conditioning our actions, transforming our values. Our concern to keep the economy sound has overwhelmed the moral repulsion we once felt against the exploitation of workers, the need we once felt to proffer social justice as an antidote to left wing extremism and union militancy, the pride we once felt as ordinary working men and women stepped forward to participate in the affairs of the nation. The economy is able to police our desires, I want to say, because "workers" and their movement are no longer there to resist. Or to put it another way, the future of labour market regulation depends not so much on the reinvention of regulatory machinery as on the recovery of social and political forces that are willing to articulate workers' interests and able to defend workers' rights.

That said, the machinery of labour market regulation is indeed in need of reinvention. Much labour law and policy was originally designed to protect "employees" who were presumed to be male, and employed full-time by a single employer over an extended period. Of course, as workplace demography has changed, we have made some adjustments: women have been accommodated by outlawing gender discrimination and providing a patchwork system of benefits and leaves to ensure social reproduction; part-time workers are sometimes provided a pro rata share of the entitlements of full-time workers; and occasionally ways are found to permit workers to retain certain benefits as they move from one job to another. But the fact remains that laws and policies based on the paradigm of the full-time, long-term male worker no longer serve us well. Some examples: 
- As labour laws and policies are adjusted to accommodate nonparadigmatic workers, their administration becomes more and more complicated for both employers and governments. Moreover, nonparadigmatic workers often have unique needs and are sometimes illserved by being assimilated to the statutory norm. And finally, these adjustments and accommodations are often perceived (however wrongly) as part of a zero sum game, in which resources are taken from "ordinary" workers and redistributed to those with "special needs".

- In North America, and to some extent elsewhere, collective bargaining tends to be organized at the workplace level; but as workers move from job to job more frequently, they are less likely to be in any one job long enough to bond with their fellow workers and form a union; workplace diversity, moreover, makes the task of bonding more difficult, and complicates the brokerage functions the union must perform in order to maintain the support of different groups in the workplace.

- Important job benefits, such as training, insurance and pensions, have traditionally been provided by employers with a view to recruiting and retaining the workers they need. In addition, governments have chosen the employment nexus as the platform from which to deliver certain programs. However, as employers come to place a higher premium on the flexibility of their workforce, as the incidence of non-standard employment rises, as job tenure shortens and employment becomes more intermittent, as more and more workers become self-employed or fall outside the statutory parameters of "employment", access to these employer-and state-provided benefits is made more difficult to maintain or denied altogether. In the absence of unions to provide or press for institutional solutions to this problem, coverage will inevitably decline. 
Other aspects of the transformation of work have likewise rendered obsolete much of the established machinery of labour market regulation. Again, I offer just a few examples:

- The shift from manufacturing to service jobs has revealed that laws premised on one sort of employment relationship do not necessarily produce the desired results when transplanted onto another. Should labour legislation be drafted to take account of sectoral differences? Or will this produce boundary disputes, undue complications in administration, complaints concerning unequal treatment and a return to corporatism?

- Globalization, as mentioned, allows employers to shift work abroad, which undercuts the ability of unions to protect their members' interests, and the willingness of workers to seek better working conditions. To counter the advantages that have accrued to employers, unions have attempted to develop transnational strategies. These include imposing restraints on the movement of work abroad, organizing foreign workers to demand decent working conditions, and enlisting the help of social movements to boycott goods produced under exploitative conditions. However, this transnational union activity is sometimes difficult to square with the law of both home and host countries; awkward to implement in countries with different types of labour markets and industrial relations systems; and risks being resented by its intended beneficiaries as an intrusion on their autonomy and culture, or as a pre-emptive move in the global competition for limited work opportunities.

- Technology has not only transformed the way work is performed; it has introduced many new items onto the regulatory agenda. For example, given the need of workers to constantly renew their skills, who should bear the cost of their doing so: the state? the employer? or the worker? 
Technology enables employers to respond to their customers 'round the clock, and globalization requires that they do so. But for employers to respond, employees must be available on at least a standby basis.

Should laws fixing maximum hours of work and requiring premium pay for overtime be changed to accommodate the employer's business needs, or the employee's needs for even greater protection against intrusion on his or her free time? Technology enables employers to maintain closer surveillance and tighter discipline over the work force. Should the law protect the right of workers to privacy and to the small acts of sabotage and subversion that privacy permits; or do they abandon that right when they enter the workplace?

\section{Conclusion}

So: I have reached some rather bleak conclusions. The transformation of work and workplaces is both a cause and an effect of the disappearance of "workers" as a political and industrial movement, as a recognizable social and cultural phenomenon, and as a distinct subject of public policy, law making and administration. But if "workers" are no more, the same cannot be said of inequality, injustice and the socially irresponsible use of power. All of these continue to thrive in our workplaces, in our communities, in our public policies. The challenge, then, is how to confront these wrongs now that we can no longer locate them within a familiar category of contention? Essentially, we face three broad choices.

One choice is to move on, to accept that "work" or "labour" is no longer available as a category of social analysis, no longer viable as a site of social mobilization. If we do accept that option, if we do move on, our most obvious strategy is to adopt the perspective of human rights. Usually framed as a series of broad principles of universal application - freedom, dignity, equality - these principles ought to apply to people at work, no less than people at other 
moments in their lives. Indeed, by recasting workers' concerns as everyone's concerns, it is possible to imagine that a new, broader and stronger coalition will emerge to support them than the coalition that once assembled in the serried ranks of the working class.

A second, less obvious, choice is to explore what has been and can be accomplished within the prevailing assumptions of global, neo-liberal capitalism. If we acknowledge that for all its negative effects, capitalism has also improved the quality of life of millions of people, it may be possible to build on that success. A century ago, in the last age of robber barons, Henry Ford paid his workers well so that they could buy his cars. In the last great depression of the 1930s, even advocates of laissez faire came to support Keynesian strategies as a form of "market correction" that would restore the confidence and purchasing power of consumers. During the technology boom of the 1990s, even notoriously selfaggrandizing employers realized that high performance work systems that "empowered" workers, invested in their welfare and rewarded their efforts generously, would increase their performance and productivity and, ultimately, corporate profits. And finally, recent proposals to "ratchet labour standards" upward seek to institutionalize this pragmatic approach that justifies the decent treatment of workers as a contribution to profitable business outcomes.

The final choice is, of course, to attempt to resuscitate or reinvent the labour movement. Some people claim to have identified "green shoots" in successful organizing campaigns amongst low-paid service workers in America; others advocate a new form of "civic unionism" in which workers and social movements would unite around the achievement of goals such as a "living wage" or "work-life balance" for everyone; and still others note that particular groups of privileged workers - professionals, skilled technicians, athletes, academics - have invented new strategies and institutions of collective action that are appropriate to their circumstances and perhaps more generally. 
The success of this last approach — of resuscitated unionism or reinvented social democracy - depends heavily on the extent to which the current crisis of capitalism arouses people's conscience and transforms their consciousness. Perhaps it will make them more aware of the precariousness of their situation, of the falsity of the doctrine of "individual responsibility" and of the fallibility of the "invisible hands" that now steer the economy; perhaps too it will remind them of the past achievements of collective worker action and of the state in its role as the guarantor of social justice. If so, it may not be too late to refurbish the old approaches to labour market regulation.

On the other hand, perhaps the current crisis will resolve itself, or leave us fearful and exhausted with no appetite for fundamental reform. And perhaps the old approaches to labour market regulation are so decrepit and discredited, or so unsuited to the new world of work, that they cannot be revived. In any of these scenarios we are left with a much larger and more difficult task: not just the resuscitation of old approaches but the total re-conceptualization of work, workers and workplace regulation.

I do take heart from the most recent history of street railways. After suffering almost total extinction in North America between the wars, as new technologies replaced them and new forms of social organization rendered them obsolete, they have reappeared under a new name and in redesigned format. Now called "light rapid transit" (or LRTs) they are now widely regarded as an indispensable feature of modern urban planning and as the very epitome of ecological responsibility. Perhaps labour standards, collective bargaining and the other discarded $20^{\text {th }}$ century technologies of labour market regulation will likewise reappear in the $21^{\text {st }}$ century, fully re-engineered, renamed and ready to serve as the vehicle of a revived workers' movement and the embodiment of a renewed vision of social justice in the workplace. 